\title{
A landscape of Communication METHODOLOGIES AND EPISTEMOLOGY
}

\author{
Sandra Marinho \& Miguel Vicente Mariño
}

Communication research progressively consolidated its presence and relevance within the Social Sciences over the course of the $20^{\text {th }}$ century. The continuous and accelerated social and technological transformations experienced since the arrival of the network society (Castells, 2000) have established Communication as one of the key emerging areas of scientific inquiry worldwide. Rooted in interdisciplinary grounds and combining various Social Sciences - such as Sociology, Psychology or Political Science - and the Humanities, Communication has proven to be a necessary research topic and an appealing new professional and academic discipline. From its initial tentative footsteps - exploring the social effects of mass media communication - to a well-grounded empirically-oriented research, Communication research has come a long way, and now faces new theoretical and practical challenges to serve as a basic and solid reference to understand contemporary societies (Norderstreng, 2004).

During the 1990 s there was an expansion of Media and Communication programmes taught by higher education institutions around the world and this continues to be a visible trend in the $21^{\text {st }}$ century, proving the social and professional demand for specialisation in this field. The number of students has remained buoyant during recent enrolment periods and this stable - if not growing - demand, has fostered parallel evolution in all related research activities. Developing professional and intellectual skills has required synchronised evolution in terms of consolidating the discipline's scientific status, at home and abroad. Institutional recognition and visibility is an ongoing struggle for this emerging field, which aims to achieve a similar status to neighbouring disciplines, and thereby enable Communication research to interact and converse in balanced interaction with other disciplines, based on mutual recognition and intellectual cooperation. The scientific struggle for scarce resources, such as research funding and institutional presence and public recognition, still exists and underpins the efforts made by Communication research to be perceived as an autonomous and specific area of production of scientific knowledge (Craig, 2008).

In order to achieve this intellectual status and social prestige, Communication research cannot forego an open discussion of its methodological and epistemological foundations (Craig, 1999). Dealing with accelerated technological innovation as one of its main topics of study should not engender weakly-grounded research outputs, if this scientific edifice is to become a solid standing point for understanding current social transformations. 
This issue of Comunicação $e$ Sociedade is underpinned by this intellectual position and offers a relevant collection of articles that explore several core aspects required to conduct well-founded studies. Furthering our relationship as Media and Communication scholars with the way that we design and apply our research is essential to strengthen our field's institutional position. The social conditions of knowledge production have turned into an appealing object of enquiry, claiming the need for epistemological reflection regarding research with a broader focus on social phenomena: short-term targets must be complemented by more in-depth analysis about what, why and how we select and approach research topics, questions and hypotheses. Conducting research in a technologically-advanced domain cannot mean leaving behind some of the main and broader philosophical questions about our role as social scientists and intellectuals. Consequently, it is still necessary to claim the need for relevant approaches to Epistemology and Methodologies, as a way to extract ourselves from regular routines in our scientific practices and institutional demands that affect the daily lives of most scholars worldwide.

Epistemological and methodological articles confront us with challenges that go beyond practical and immediate research-related decisions, and require us to take a step backwards and observe our decisions with greater time, so as to develop a critical approach to their meaning. This moment of reflection will enable researchers to understand the relevance of their own specific solutions, broadening analytical perspectives and exploring relevant aspects of their research that usually remain outside dominant frameworks oriented towards short-term decisions. A brief look at the contents of this issue will demonstrate that one must not link these methodological and epistemological contributions solely to more traditional research topics, since these classical questions are applied to the most recent innovations currently being developed in modern societies. Exploring the way that research is conducted within the global context of big data, or the omnipresent spaces of online social networks, are only two indications of the need to build the necessary conditions to maintain dialogue between long and short-term questions about the way our research is conducted (Hutchinson, 2016).

The technological evolution currently underway in the media and communication sector are also affecting the research schema and practices in this field. Our analytical toolkit may still include some of the classical theoretical questions and approaches, but the digital transformation and computational shift that has been experienced since, at least, the transition to the $21^{\text {st }}$ century is obviously redefining our role and habits in terms of scientific enquiry. Teaching Media Studies and Communication Research requires keeping abreast of these innovations and striking a balance with the classical and still relevant core questions regarding the role played by Communication in various types of social exchange. How can this balance be achieved and, if possible, maximised? This is one of the main challenges facing Communication research as a scientific field and/ or discipline: advancing with increasing intellectual confidence and empirically-based evidence down a road filled with new external stimuli that challenge our main research questions, in terms of why and how we try to solve them. It is necessary to maintain a critical approach to exploring digital environments, in order to ensure our role as social 
scientists and committed citizens. If this issue of Comunicação e Sociedade helps us draw closer to some answers to these questions, then the effort to forge a coherent collection of interesting and readable articles will have been worthwhile.

On the basis of the reflections included within this issue of Comunicação e Sociedade, we can see that the field of Methodologies is increasingly viewed as a space of dialogue, and sometimes tension, between the various paradigms (or approaches) of Communication research and theories. When we consider the vast field, constituted by Epistemology and Philosophy of Science, that articulate Ethics and the more operational aspect of methods and techniques, we have a wide space of debate about their uses and potentialities, and also the challenges that all these dimensions pose to Communication researchers.

Recognition of the importance of Research Methodologies also exists in the framework of Communication teaching, through integration of curricular units of this nature in study plans, which varies in different academic contexts. In the case of Portugal and Spain, for example, there has been a reduction in the curricular weight of the Social and Human Sciences in Communication and Journalism courses, which necessarily entails a decrease in the presence of Methodologies (Sanchéz-García \& Marinho, 2015).

When this recognition occurs, the existence of content dedicated to Methodology and the very approaches that such content favours often pay testimony to the epistemological orientation that presides over the creation of course study plans and the way that they fit into the field of Social and Human Sciences. In this issue of the journal, Comunicação e Sociedade, we have tried to create space for both realities - education and research - and the diversity of epistemological positions that characterise this field.

Another indicator of the importance attributed to Methodologies is its representativeness within scientific journals. Without aiming to provide a comprehensive overview, it is possible to identify several publications that focus on "quantitative methods" and "qualitative methods", in the context of "research ethics", and on "epistemology", "philosophy of science" or specific methods, such as the Action Research Journal, which is dedicated to "action research". The number of examples is drastically reduced if we focus on the field of Communication. In this case we can highlight Communication, Methods and Measures or, at a narrower level, the Journal of Information Communication and Ethics in Society. If we extend this rationale to scientific associations, the attention paid to Research Methodology is still fairly limited: IAMCR (International Association for Media and Communication Research) does not have any section dedicated to the subject; the closest area within ICA (International Communication Association) is the department of "Philosophy, theory and critique" and an interest group on "Computational Methods". In the same vein, ECREA (European Communication Research and Education Association) has a section on "Philosophy of Communication" and, notably, AEJMC (Association for Education in Journalism and Mass Communication), has a section on "Communication Theory and Methodology". In Portuguese-speaking countries and the Ibero-American context, there appears to be a greater concern with these issues. ALAIC (Latin American Association of Communication Researchers) has a working group dedicated to the 
"Theory and Methodology of Communication Research"; Assibercom (Ibero-American Communication Association) has a thematic department for "Epistemology, Theory and Methodology of Research"; and Intercom (Brazilian Society of Interdisciplinary Communication Studies) has a research group on "Theories of Communication", with an epistemological / methodological approach. At the 2017 congress of Agacom (Galician Association of researchers in communication) the programme included a thematic panel on "Theories, methods and techniques of communication research and reception", and in 2016, at the congress of Lusocom (Lusophone Federation of Communication Sciences) there was a working group on "Epistemology of Communication" (but this was not included in the 2018 congress programme). Sopcom (Portuguese Association of Communication Sciences) does not have any working group dedicated to Epistemology and Methodology of Communication.

We also note the concern to look at Research Methodologies from another perspective: trying to verify which approaches, methodologies, methods and techniques are most used by researchers who publish in the field of the Communication Sciences. For example, we can mention the work of Trumbo (2004), who evaluated the editions of eight leading international journals in this field between 1990 and 2000. There are other similar publications, some of which are pioneers in this effort of meta-analysis of the field (Brashers \& Jackson, 1999; Cooper, Potter \& Dupagne, 1994; Emmers-Sommer \& Allen, 1999; Kamhawi \& Weaver, 2003; Lowry, 1979; Perloff, 1976; Riffe \& Freitag, 1997; Schramm, 1957; Weaver, 1988; Weaver, 1993; Wimmer \& Haynes, 1978 quoted in Trumbo, 2004).

This edition of Comunicação e Sociedade arises in this context of the limited representativeness of Research Methodologies in the field of Communication, at least from the point of view of scientific production and dissemination. We thereby aim to make a small contribution to this much-needed debate, in the hope that it will become more frequent.

We can now provide a brief overview of this issue.

The issue begins with an essay, in which Cicilia Peruzzo uses her experience as a Communication researcher, with special interest in the field of methodologies, to trace a critical panorama of the uses and development of Epistemology and Methodology in research into Communication Sciences in Brazil. This is followed by an article by Lumárya Souza de Sousa and Thaiane Oliveira who argue that action research can be constituted as the aggregating axis of an epistemology of the South, based on mapping use of this method, also in the Brazilian context. We therefore begin this issue with two macro-level texts, which discuss research paradigms and cross-cutting epistemological issues in the field of Communication research.

We continue with four texts, at a meso-level, that address Research Methodologies, focused on specific fields of studies in the world of Communication. Francisco Paulo Jamil Marques and Edna Miola analyse scientific production in the field of Communication and Politics, in Brazil, in order to identify their most relevant epistemological and methodological progress and obstacles and offer some proposals to overcome these obstacles. This is followed by two articles on Big Data and network analysis, both with 
critical perspectives regarding methodological approaches that could / should be adopted in these fields. Ana Thereza Nogueira Soares argues in favour of a critical position towards the epistemological, methodological and theoretical implications of Big Data research (in particular based on social media data) for the scientific field of Communication, with special focus on the need to value the theoretical domain in this area. Francisco Conrado Filho and Luís António Santos also highlight the importance of theoretical and conceptual perspectives for Social Network Analysis (ARS). For this purpose, they provide an overview of the different approaches that can be adopted, highlighting their added value and risks. This article also has a pedagogical nature, since it may serve as an introductory reading for anyone commencing a course in Analysis of Social Networks. We close this meso-level section with an essay by Pedro de Andrade on Urban Cultural Tourism, in which the author analyses what are considered to be the main methodologies in the field of Artistic Sociology to defend a new approach, based on the concepts of "hybridisation" and "mobile cultures".

The following two articles focus on specific procedures, including micro-level discussions in the context of the approach to Research Methodologies that we have adopted here. Ruth de Frutos and Diego Giannone are concerned with evaluating the methodological challenges posed by the two most important world press freedom indexes - Freedom House and Reporters Without Borders - to show to what extent these instruments are deficient, in particular in terms of the absence of mechanisms for protection of journalists as a variable. Rita de Cássia Romeiro Paulino and Marina Lisboa Empinotti write about the theoretical-methodological foundation of the process of constructing a model to evaluate the production of journalistic content (news) for mobile devices (smartphones), using a card-like interface.

Cláudio Márcio Magalhães is the author of the only article in this issue of Comunicação e Sociedade that is primarily focused on teaching. She doesn't focus on current teaching of Research Methodologies, but rather the development of a pedagogical strategy (using research techniques) to teach a theoretical concept (in this case, Motivation) within a discipline in the field of Communication (more specifically the area of Advertising and Propaganda).

The articles section concludes with a contribution focused on Ethics - a primordial and transversal area for Research Methodologies. Fernanda Pires de Sá discusses the concerns and ethical challenges that arise during a research project (in this case, co-viewing of a telenovela soap opera), to reveal that ethical considerations should be included not only at the beginning of a research project, but also throughout each step of the process, in a continuous process of adjustment.

This issue ends with two literature reviews. Eduardo Francisco Rodríguez Gómez reviews a book on Communication Research Methodologies, a manual of synthesis and mapping of the field, which seeks to bridge Communication Research Methods and Theories. The second review, by Madalena Oliveira, is about a book (a collective work) specifically dedicated to dealing with different perspectives adopted in the analysis of radio. Whereas the first book seeks to constitute a different approach in a field where 
there is already consistent production (manuals on Research Methodology), the second book is the result of a contribution to an area where there is scarce, almost non-existent, production.

In 2007, the first issue of the journal Communication, Methods and Measures, stated that there is a "clear and defensible need" (Roskos-Ewoldsen, Aakhus, Hayes, Heider \& Levine, 2007, p. 2) for a publication exclusively dedicated to Methodology in the field of Communication. This idea was reiterated ten years later, in the same journal, as a balancing factor (Matthes, Niederdeppe \& Shen, 2016). Since we share this perspective - i.e. that it is crucial to foster debate on Research Methodologies in the field of Communication Sciences - we consider that this issue of Comunicação e Sociedade is relevant. This is not because this topic has been ignored by this journal - like other international scientific journals, we have previously published articles focused on methodological issues (Costa, 2000; Damásio, Henriques \& Mackart, 2012; F. Lopes, 2009; M. I. V. Lopes, 2000) - but we consider that this issue shouldn't be highlighted as a one-off event.

Translated by Martin Dale (Formigueiro, Conteúdos Digitais, Lda)

\section{BibLIOGRAPHIC REFERENCES}

Castells, M. (2000). The rise of the network society. The information age: economy, society and culture. Hoboken, New Jersey: John Wiley \& Sons.

Costa, M. S. (2000). As ciências da comunicação: consolidação académica e desafios interdisciplinares. Comunicação e Sociedade, 2, 71-76. doi: 10.17231/comsoc.2(2000).1383

Craig, R. T. (1999). Communication theory as a field. Communication Theory, 9(2), 119-161. doi: 10.1111/j.14682885.1999.tboo355.x

Craig, R. T. (2008). Communication in the conversation of disciplines. Russian Journal of Communication, 1(1), 7-23. doi: 10.1080/19409419.2008.10756694

Damásio, M. J., Henriques, S. \& Mackert, M. (2012). Saúde electrónica e literacia em saúde: uma revisão da metodologia de pesquisa. Comunicação e Sociedade (Vol. Especial), 171-183. doi: 10.17231/ comsoc.23(2012).1362

Hutchinson, J. (2016). An introduction to digital media research methods: how to research and the implications of new media data. Communication Research and Practice, 2(1), 1-6. doi: $10.1080 / 22041451.2016 .1155307$

Lopes, F. (2009). Estudos televisivos: perspectivas diacrónicas. Comunicação e Sociedade, 15, 7-27. doi: $10.17231 /$ comsoc.15(2009).1042

Lopes, M. I. V. (2000). Metodologia para o estudo de recepção de telenovelas no Brasil. Comunicação e Sociedade, 2, 93-112. doi: 10.17231/comsoc.2(2000).1386

Matthes, J., Niederdeppe, J. \& Shen, F. C. (2016). Reflections on the need for a journal devoted to communication research methodologies: ten years later. Communication Methods and Measures, 10(1), 1-3. doi: 10.1080/19312458.2016.1136514 
Norderstreng, K. (2004). Ferment in the field: notes on the evolution of communication studies and their disciplinary nature. Javnost - The Public, 10(3), 5-18. doi: 10.1080/13183222.2004.11008856

Roskos-Ewoldsen, D., Aakhus, M., Hayes, A. F., Heider, D. \& Levine, T. (2007). It's about time: the need for a journal devoted to communication research methodologies. Communication Methods and Measures, 1(1), 1-5. doi: 10.1080/19312450709336657

Sanchéz- García, P. \& Marinho, S. (2015). La enseñanza universitaria encaminada a la especialización y al recorte de Humanidades: estudio de caso de la titulación de Periodismo en España y Portugal. RIESED - Revista Internacional de Estudios sobre Sistemas Educativos, 4, 17-36. Retrieved from http://www.riesed. org/index.php/RIESED/article/view/69

Trumbo, C. (2004). Research methods in mass communication research: a census of eight journals 19902000. Journalism and Mass Communication Quarterly, 81(2), 417- 436. doi: 10.1177/107769900408100212

\section{BIOGRAPHICAL NOTES}

Sandra Marinho has a doctorate in Communication Sciences, in the area of Journalism Studies, at the University of Minho. She is an Assistant Professor at this University, where she teaches in the areas of Research Methodologies and Journalism.

She is a researcher at the Centro de Estudos de Comunicação e Sociedade (CECS) and her main research areas are the quality of journalism and of journalism education and health journalism. She has published in several national and international journals.

E-mail: marinho@ics.uminho.pt

Address: Centro de Estudos de Comunicação e Sociedade

Campus de Gualtar

4710-057 Braga, Portugal

Miguel Vicente Mariño is an Associate Professor and Head of the Department of Sociology and Social Work at the University of Valladolid, based in the Faculty of Social, Legal and Communication Sciences. He holds a PhD in Audiovisual Communication, a BA in Sociology and a BA in Journalism. He is a member of the Executive Committee of ECREA (European Communication Research and Education Association), deputy director of the Audience section of IAMCR (International Association for Media and Communication Research) and of the Working Group on the History of Communication Research of the Spanish Association of Communication Research. His research topics include the study of media and social audiences, environmental communication, the processes of public opinion formation in current societies, and Communication Research methods.

E-mail:miguelvm@soc.uva.es

Address: Universidad de Valladolid - Campus de Segovia

Plaza de la Universidad, 1. 40005 Segovia 